\title{
Translation, cross-cultural adaptation, and reliability of the Workplace Sitting Breaks Questionnaire into Brazilian Portuguese
}

\author{
Alexandre Reinaldo Silva ${ }^{1}$, Cid André Fidelis de Paula Gomes² (1), \\ José Edson França da Silva Júnior² (1D, Daniel Santos Rocha (1), \\ Cezar Augusto Brito Pinheiro 3 (1) Almir Vieira Dibai-Filho ${ }^{3,4 *}$ (1), Daniela Bassi-Dibail,5 (1)
}

\section{SUMMARY}

OBJECTIVE: This study aimed to translate, adapt, and analyze the reliability of the Workplace Sitting Breaks Questionnaire (SITBRQ) for use in Brazil. METHODS: This is a cross-sectional study. The translation and cross-cultural adaptation were conducted considering the following six phases: translation, synthesis of translations, back translation, analysis by a committee of experts, test of the pre-final version, and final version. We included workers aged 18 years or above, both genders, and able to understand, read, and write in Brazilian Portuguese. The final version was applied to workers in two moments (i.e., test and retest), with an interval of 7 days, for reliability calculation. RESULTS: In the translation and cross-cultural adaptation phase, the pre-final version was applied to a sample of 35 workers. For item a of the SITBRQ, there was $100 \%$ understanding by respondents, while item b was understood by $94.28 \%$. The reliability phase was conducted with 115 workers. For both items, almost perfect was identified with kappa $>0.81$.

CONCLUSIONS: The SITBRQ version into Brazilian Portuguese has adequate adaptation and excellent values of reliability. KEYWORDS: Occupational health. Surveys and questionnaires. Sedentary behavior.

\section{INTRODUCTION}

Occupational activities, such as standing or performing household tasks, are considered mild physical activities. It is known that individuals with low levels of light-intensity physical activity are more likely to exhibit sedentary behaviors ${ }^{1,2}$. Furthermore, it is suggested that high levels of light-intensity physical activity are related to a reduction in the risk of overweight and/or obesity and a consequent reduction in the risk of developing cardiometabolic diseases ${ }^{3-5}$.

Understanding this context and relating professional activities that do not allow walking during working hours, remaining seated for long periods, and favoring a decrease in the willingness to perform simple tasks, it is recommended that workers take few minutes break during their workday. These short breaks favor the reduction of both the biomechanical overload resulting from the posture maintained throughout the working day and the risk of occupational and systemic disorders ${ }^{6,7}$.

For this reason, in recent years, the development of instruments that aim to analyze the behavior of breaks during the performance of work activities has intensified ${ }^{8}$. Among these, the formulation of the Workplace Sitting Breaks Questionnaire (SITBRQ) stands out ${ }^{8}$. Developed for the English language,

\footnotetext{
'Universidade Ceuma, Departamento de Fisioterapia - São Luís (MA), Brazil.

2Universidade Nove de Julho, Programa de Pós-Graduação em Ciências da Reabilitação - São Paulo (SP), Brazil.

${ }^{3}$ Universidade Federal do Maranhão, Departamento de Educação Física - São Luís (MA), Brazil.

${ }^{4}$ Universidade Federal do Maranhão, Programa de Pós-Graduação em Educação Física - São Luís (MA), Brazil.

${ }^{5}$ Universidade Ceuma, Programa de Pós-Graduação em Gestão de Programas e Serviços de Saúde - São Luís (MA), Brazil.

*Corresponding author: dibaifilho@gmail.com

Conflicts of interest: the authors declare there is no conflicts of interest. Funding: this work as partially supported by Conselho Nacional de Desenvolvimento Científico e Tecnológico (PIBIC/CNPq), Fundação de Amparo à Pesquisa e ao Desenvolvimento Científico e Tecnológico do Maranhão (PIBIC/FAPEMA), and Coordenação de Aperfeiçoamento de Pessoal de Nível Superior (CAPES, finance code 001).

Received on August 18, 2021. Accepted on August 19, 2021.
} 
the SITBRQ presents satisfactory validity and reliability when compared with other self-report instruments related to the study of sedentary behavior. Presenting as positive points the reduced filling time and ease of understanding and interpretation ${ }^{8}$.

In Brazil, although the literature presents numerous instruments that assess physical and labor activity, none of these measure short breaks in working time by sitting. Knowing this, the adaptation and validation of a new self-report instrument capable of evaluating breaks during the sitting time in work activity are justified, facilitating the analysis and implementation of more assertive healthcare strategies for this population.

Our hypothesis is that the SITBRQ, after going through the process of translation and cross-cultural adaptation into Brazilian Portuguese, is reliable for application in this population. The aim of this study was to translate and cross-culturally adapt the SITBRQ into Brazilian Portuguese and to verify the test-retest reliability of this version.

\section{METHODS}

\section{Study design}

This is a cross-sectional study conducted according to the Guidelines for the Process of Cross-Cultural Adaptation of Self-Report Measures ${ }^{9}$ and the Consensus-Based Standards for the Selection of Health Measurement Instruments (COSMIN) $)^{10}$. Authorization to perform the cross-cultural adaptation of the SITBRQ into Brazilian Portuguese was granted via email by one of the authors of the original version of the questionnaire (Dr. Željko Pedišić).

This study was approved by the institution's Research Ethics Committee (number 4,555,379). Participants were recruited by means of social media, text messaging, and email. All recruited volunteers gave consent to participate in this study. Data collection took place online. The questionnaire was made available on the Google Forms platform (Mountain View, CA, USA).

\section{Translation and cross-cultural adaptation}

The translation and cross-cultural adaptation process of the SITBRQ into Brazilian Portuguese followed the following criteria.

1. Translation: two independent translators, namely, a physiotherapist with above 10 years of experience and an English teacher with above 21 years of experience in translations, however without technical knowledge of matters in the health area. They translated the original version of the SITBRQ into Brazilian Portuguese. It is important to highlight that both had Brazilian Portuguese as their mother tongue and were fluent in English.

2. Synthesis of translations: after discussions and potential revisions, the two translators, under observation by the responsible researcher, synthesized the two versions of the questionnaire translated independently. Thus, they produced a single version of the SITBRQ in a consensual manner.

3. Back translation: two independent translators, with English as their mother tongue and fluent in Portuguese, translated the Portuguese version of the SITBRQ back into English. It is important to highlight that both did not have technical knowledge in the area of health or even had prior knowledge about the original version of the questionnaire.

4. Analysis by a committee of experts: the four translators involved in the adaptation process met together with four experts in the field with experience in the health field, specifically in occupational health. Together, they reviewed all translated and back-translated versions to correct possible discrepancies. In this way, the pre-final version of the SITBRQ was obtained in an agreed manner among all members of the committee.

5. Test of the pre-final version: the pre-final version of the SITBRQ was applied to 30 Brazilian workers. Participants read and filled out the questionnaire, and at the end of filling it out, they established their understanding of the pre-final version of the SITBRQ by checking a checkbox containing the answers "yes" and "no" for each item in the questionnaire. To be considered as having an adequate degree of understanding, the items must be understood by at least $80 \%$ of the participants.

6. After analyzing the pre-final version, the coordinator of the adaptation process thus established the final version of the SITBRQ in Brazilian Portuguese.

\section{Participants}

The minimum sample for this study was characterized as 100 participants ${ }^{10}$. Specifically, to obtain test-retest reliability, the SITBRQ was applied on two occasions, with an interval of 7 days between assessments ${ }^{11}$.

For this, the following inclusion criteria were adopted: active workers with at least 6 months in the same job, aged 18 years or above, both genders, and ability to understand, read, and write in Brazilian Portuguese. Exclusion criteria were the presence of diagnosed cognitive diseases and not responding to the retest. The inclusion and exclusion criteria were applied based on the worker's self-report since data collection was performed online.

\section{Workplace Sitting Breaks Questionnaire}

The SITBRQ consists of two items ( $a$ and $b$ ), which assess the frequency and duration of breaks from work in a work environment in which workers usually sit down to carry out tasks. The first item asks about how many breaks the worker takes when leaving the sitting position (whether to drink water, take 
a short walk, or even stretch), with seven answer options (0-6 or more up). The second item asks about the time spent by the worker in short-term physical activities, such as getting up from a chair and having a drink, or going to the bathroom, or continuing a task while standing. This item also has seven response options (60 $\mathrm{min}$ or more; 30-59 $\mathrm{min}$; 20-29 min; 10-19 min; 5-9 min; <5 min; not applicable). SITBRQ has no score. Items must be analyzed separately.

\section{Statistical analysis}

To characterize the sample, descriptive statistics were performed with the presentation of quantitative data by means of mean and standard deviation (SD) and qualitative data by means of absolute number and percentage. The reliability analysis of the SITBRQ was performed using the kappa test with linear weighting. We considered the following interpretation of kappa values: $<0$, poor; $0.01-0.20$, light; $0.21-0.40$, reasonable; $0.41-0.60$, moderate; $0.61-0.80$, substantial; and $0.81-1$, almost perfect ${ }^{12}$.

Data processing was performed using the SPSS software, version 17.0 (Chicago, IL, USA), and the calculation of kappa with linear weighting was performed using the website http://vassarstats.net/ kappa.html. For all analyses, a significance level of $5 \%$ was considered.

\section{RESULTS}

In the SITBRQ translation and cross-cultural adaptation phase, the expert committee decided to make the following two changes in the questionnaire:

1. The removal of redundant information in the instructions for completing the questionnaire; and

2. The insertion of examples of short physical activities in item $b$ of the questionnaire. Thus, the pre-final version of the SITBRQ was established.

The pre-final version was applied to a sample of 35 Brazilian workers. Of these, $20(57.1 \%)$ were women, with a mean age of 40.94 years $(S D=13.75)$. For item a of the SITBRQ, there was $100 \%$ understanding by respondents, while item $b$ was understood by $94.28 \%$ of respondents. Thus, the final version of SITBRQ was established (Figure 1).

\section{VERSÃO BRASILEIRA DO WORKPLACE SITTING BREAKS QUESTIONNAIRE (SITBRQ)}

Nós desejamos avaliar se você faz pausas ou intervalos nas suas tarefas durante o horário de trabalho. Durante um dia normal de trabalho, podem surgir oportunidades para você fazer pequenos intervalos durante as suas tarefas de trabalho e realizar atividades físicas curtas, ou seja, qualquer interrupção no tempo em que você fica sentado(a) no trabalho. Por exemplo, deslocar-se pelo seu local de trabalho para tomar uma bebida, ir ao banheiro ou até mesmo continuar uma tarefa de trabalho enquanto estiver em pé.

Circule uma resposta para as seguintes perguntas.

a. Em um dia normal de trabalho, quantas pausas durante uma hora de trabalho na posição sentada você faz (como levantar-se, alongar-se ou fazer uma curta caminhada)?

b. Durante um dia típico no trabalho, qual é o tempo total gasto por você para realizar atividades físicas curtas (como se deslocar pelo seu local de trabalho para tomar uma bebida, ir ao banheiro ou até mesmo continuar uma tarefa de trabalho enquanto estiver em pé)?

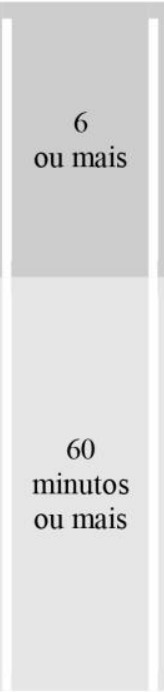

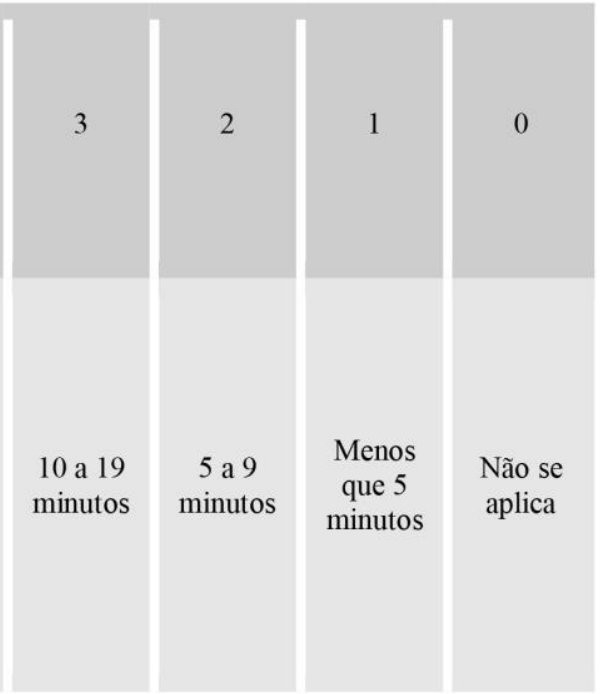

Figure 1. Brazilian version of the Workplace Sitting Breaks Questionnaire. 
Therefore, the final version was applied to 115 workers in two moments (i.e., test and retest), with an interval of 7 days between evaluations. As shown in Table 1, most of the sample was made up of men, young adults, singles, and with a weekly workload of more than $35 \mathrm{~h}$. Table 2 shows the reliability values of the SITBRQ. Almost perfect reliability was observed in the two items of the questionnaire, with kappa values $>0.81$.

Table 1. Characterization of the study sample $(n=115)$.

\begin{tabular}{|c|c|}
\hline Variable & $\begin{array}{c}\text { Mean (standard } \\
\text { deviation) or number (\%) }\end{array}$ \\
\hline Age (years)* & $28.97(10.84)$ \\
\hline Sex $(\text { male })^{\dagger}$ & $59(51.3)$ \\
\hline \multicolumn{2}{|l|}{ Marital status ${ }^{\dagger}$} \\
\hline Single & $75(65.2)$ \\
\hline Married & $36(31.3)$ \\
\hline Widower & $1(0.9)$ \\
\hline Divorced & $3(2.6)$ \\
\hline \multicolumn{2}{|l|}{ Education $^{+}$} \\
\hline Basic education & $8(6.9)$ \\
\hline High school & $71(61.8)$ \\
\hline University education & $36(31.3)$ \\
\hline Weight $(\mathrm{kg})^{*}$ & $75.46(17.92)$ \\
\hline Height $(m)^{\star}$ & $1.68(0.10)$ \\
\hline Body mass index $\left(\mathrm{kg} / \mathrm{m}^{2}\right)^{*}$ & $26.44(4.73)$ \\
\hline Physical activity (yes) ${ }^{\dagger}$ & $49(42.6)$ \\
\hline Working time (months)* & $78.26(97.19)$ \\
\hline Weekly workload (h)* & $35.96(13.65)$ \\
\hline \multicolumn{2}{|l|}{ Postures at work ${ }^{\dagger}$} \\
\hline Standing & $42(36.5)$ \\
\hline Seated & $41(35.6)$ \\
\hline Standing and sitting & $32(27.9)$ \\
\hline \multicolumn{2}{|l|}{ Kind of work ${ }^{\dagger}$} \\
\hline Manual & $48(41.7)$ \\
\hline Nonmanual & $9(7.8)$ \\
\hline Manual and nonmanual & $48(41.7)$ \\
\hline Others & $10(8.7)$ \\
\hline \multicolumn{2}{|l|}{ Ongoing treatments $^{\dagger}$} \\
\hline Medicative & $41(35.7)$ \\
\hline Physiotherapeutic & $23(20.0)$ \\
\hline Psychotherapeutic & $16(13.9)$ \\
\hline
\end{tabular}

\section{DISCUSSION}

The translation and adaptation of the SITBRQ into Brazilian Portuguese proved to be adequate for the population studied, resembling the original version applied in the Australian population ${ }^{8}$. However, the Brazilian Portuguese version was actually tested on individuals who performed continuous work activities, with an average weekly workload of $35.96 \mathrm{~h}$, the predominance of standing or sitting posture, associated with a low level of physical activity, similar to office workers ${ }^{13}$.

For the two items that make up the questionnaire, kappa values $>0.81$ were found, exceeding the values reported in the original version ${ }^{8}$, which presented acceptable values, however lower than those in this study ( 0.74 and 0.61 for items 1 and 2 , respectively). We believed that this difference is related to the better defined profile of the participants included in this study, much closer to the reality of individuals who carry out continuous work activities ${ }^{13}$.

Understanding that individuals with a low level of activities characterized as short have greater sedentary behavior ${ }^{1,2}$, the SITBRQ appears as a simple, easy-to-understand, quick-filling tool to measure the frequency of breaks, and the total time spent on short physical activities during work ${ }^{8}$. Potentially, it can be used in epidemiological studies and mainly as a facilitator for

Table 2. Test-retest reliability of the Workplace Sitting Breaks Questionnaire (SITBRQ).

\begin{tabular}{|c|c|c|c|}
\hline SITBRQ items & $\begin{array}{l}\text { Test, } \\
\mathrm{n}(\%)\end{array}$ & $\begin{array}{l}\text { Retest, } \\
\mathrm{n}(\%)\end{array}$ & $\begin{array}{l}\text { Kappa } \\
(95 \% \mathrm{Cl})\end{array}$ \\
\hline \multicolumn{4}{|l|}{ Item a } \\
\hline 6 or more & $22(19.1)$ & $19(16.5)$ & \multirow{7}{*}{$\begin{array}{c}0.817 \\
(0.665-0.956)\end{array}$} \\
\hline 5 & $6(5.2)$ & $10(8.7)$ & \\
\hline 4 & $6(5.2)$ & $7(6.1)$ & \\
\hline 3 & $20(17.4)$ & $22(19.1)$ & \\
\hline 2 & $21(18.3)$ & 19 (16.5) & \\
\hline 1 & $20(17.4)$ & $23(20.0)$ & \\
\hline 0 & $20(17.4)$ & 15 (13.0) & \\
\hline \multicolumn{4}{|l|}{ Item b } \\
\hline $60 \mathrm{~min}$ or more & $22(19.1)$ & $23(20)$ & \multirow{7}{*}{$\begin{array}{c}0.815 \\
(0.730-0.900)\end{array}$} \\
\hline 30-59 min & $23(20.0)$ & $23(20)$ & \\
\hline 20-29 min & $8(7.0)$ & $11(9.6)$ & \\
\hline 10-19 min & $14(12.2)$ & $17(14.8)$ & \\
\hline $5-9 \min$ & $28(24.3)$ & $25(21.7)$ & \\
\hline$<5 \min$ & $17(14.8)$ & $14(12.2)$ & \\
\hline Not applicable & $3(2.6)$ & $2(1.7)$ & \\
\hline
\end{tabular}

Cl: confidence interval. 
the development of more assertive strategies in relation to prevention and promotion of healthcare, aiming to reduce sedentary behavior in the work environment ${ }^{14}$.

This study is the first cross-cultural adaptation of the SITBRQ, and this fact considerably limited the discussion of the data. Thus, we suggest that further studies should be carried out in other languages and cultures considering the importance of the aspects assessed by the questionnaire for workers' health.

\section{CONCLUSION}

The adapted version of the SITBRQ into Brazilian Portuguese has adequate reliability.

\section{AUTHORS" CONTRIBUTIONS}

ARS: Conceptualization, Data curation, Formal analysis, Methodology, Writing - original draft. CAFPG: Conceptualization, Data curation, Formal analysis, Methodology, Project administration, Writing - review \& editing. JEFSJ: Conceptualization, Data curation, Formal analysis, Methodology, Writing - original draft. DSR: Conceptualization, Data curation, Formal analysis, Methodology, Writing - original draft. CABP: Conceptualization, Data curation, Formal analysis, Methodology, Writing - original draft. AVDF: Conceptualization, Data curation, Formal analysis, Methodology, Writing - review \& editing. DBD: Conceptualization, Data curation, Formal analysis, Methodology, Project administration, Writing - review \& editing.

\section{REFERENCES}

1. Buman MP, Hekler EB, Haskell WL, Pruitt L, Conway $T L$, Cain $\mathrm{KL}$, et al. Objective light-intensity physical activity associations with rated health in older adults. Am J Epidemiol. 2010;172(10):1155-65. https://doi.org/10.1093/aje/kwq249

2. Carson V, Ridgers ND, Howard BJ, Winkler EAH, Healy GN, Owen $\mathrm{N}$, et al. Light-intensity physical activity and cardiometabolic biomarkers in US adolescents. PLoS One. 2013;8(8):e71417. https://doi.org/10.1371/journal.pone.0071417

3. Dunstan DW, Kingwell BA, Larsen R, Healy GN, Cerin E, Hamilton MT, et al. Breaking up prolonged sitting reduces postprandial glucose and insulin responses. Diabetes Care. 2012;35(5):976-83. https://doi.org/10.2337/dc11-1931

4. Healy GN, Dunstan DW, Salmon J, Cerin E, Shaw JE, Zimmet $\mathrm{PZ}$, et al. Objectively measured light-intensity physical activity is independently associated with 2-h plasma glucose. Diabetes Care. 2007;30(6):1384-9. https://doi.org/10.2337/dc07-0114

5. Pescatello LS, Murphy D, Costanzo D. Low-intensity physical activity benefits blood lipids and lipoproteins in older adults living at home. Age Ageing. 2000;29(5):433-9. https://doi. org/10.1093/ageing/29.5.433

6. Garber CE, Blissmer B, Deschenes MR, Franklin BA, Lamonte MJ, Lee IM, et al. American College of Sports Medicine position stand. Quantity and quality of exercise for developing and maintaining cardiorespiratory, musculoskeletal, and neuromotor fitness in apparently healthy adults: guidance for prescribing exercise. Med Sci Sports Exerc. 2011;43(7):1334-59. https:// doi.org/10.1249/MSS.0b013e318213fefb

7. Healy GN, Dunstan DW, Salmon J, Cerin E, Shaw JE, Zimmet $P Z$, et al. Breaks in sedentary time: beneficial associations with metabolic risk. Diabetes Care. 2008;31(4):661-6. https://doi. org/10.2337/dc07-2046
8. Pedisic Z, Bennie JA, Timperio AF, Crawford DA, Dunstan DW, Bauman $A E$, et al. Workplace Sitting Breaks Questionnaire (SITBRQ): an assessment of concurrent validity and test-retest reliability. BMC Public Health. 2014;5,14:1249. https://doi. org/10.1186/1471-2458-14-1249

9. Beaton DE, Bombardier C, Guillemin F, Ferraz MB. Guidelines for the process of cross-cultural adaptation of self-report measures. Spine (Phila Pa 1976). 2000;25(24):3186-91. https:// doi.org/10.1097/00007632-200012150-00014

10. Gagnier JJ, Lai J, Mokkink LB, Terwee CB. COSMIN reporting guideline for studies on measurement properties of patientreported outcome measures. Qual Life Res. 2021;30(8):2197218. https://doi.org/10.1007/s11136-021-02822-4

11. Bassi $D$, Santos-de-Araújo $A D$, Camargo PF, Dibai-Filho $A V$, da Fonseca MA, Mendes RG, et al. Inter and intra-rater reliability of short-term measurement of heart rate variability on rest in diabetic type 2 patients. J Med Syst. 2018;42(12):236. https:// doi.org/10.1007/s10916-018-1101-8

12. Sim J, Wright CC. The kappa statistic in reliability studies: use, interpretation, and sample size requirements. Phys Ther. 2005;85(3):257-68. PMID: 15733050

13. Nooijen CFJ, Kallings LV, Blom V, Ekblom Ö, Forsell Y, Ekblom MM. Common perceived barriers and facilitators for reducing sedentary behaviour among office workers. Int J Environ Res Public Health. 2018;15(4):792. https://doi.org/10.3390/ ijerph15040792

14. Prince SA, Cardilli L, Reed JL, Saunders TJ, Kite C, Douillette $K$, et al. A comparison of self-reported and device measured sedentary behaviour in adults: a systematic review and metaanalysis. Int J Behav Nutr Phys Act. 2020;17(1):31. https:// doi.org/10.1186/s12966-020-00938-3 